\title{
Providing service without altering the ecological balance of knowledge: the sustainability of Ibero-American nursing journals
}

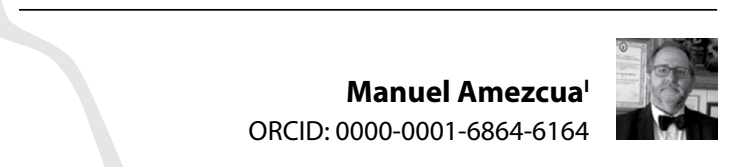

'President of the Fundación Index. Granada, Spain.

How to cite this article: Amezcua M. Providing service without altering the ecological balance of knowledge: the sustainability of Ibero-American nursing journals. Rev Bras Enferm. 2021;74(2):e740201. https://doi.org/10.1590/0034-7167.2021740201
When talking about sustainability from the economy or ecology, we are referring to the ability to produce goods and services without depleting resources or harming the environment. If we apply the concept to the field of scientific publication, sustainability could refer to the possibility of maintaining an infrastructure of publications capable of disseminating the knowledge produced by an area of knowledge, with independent and autonomous editorial resources and without harming the natural environment of the discipline it represents. Scientific publication is a good in itself, insofar as it contributes to the development of science, but in order to be sustainable there must be a balance in its ecological, economic and social dimension ${ }^{(1)}$. From here, the question arises: does Ibero-American nursing have a support for sustainable scientific publication? In order to give an answer that is as objective as possible, it is advisable to support it with data.

Ibero-American nursing has a base of periodical publications that has been consolidated in recent decades. If we stick to the information provided by Cuiden, the platform that incorporates most of the IberoAmerican nursing production ${ }^{(2)}$, since the beginning of the 1990s, 157 journals (REHIC Catalog) can be identified, most of them produced in Spain (47\%) and in Brazil (30\%) But only a third of them registered bibliometric impact in 2019 according to Cuiden Citación ${ }^{(3)}$. The nursing journals of the Ibero-American Scientific Space (ECI) have published an average of just over 5,000 documents per year in the past decade, showing signs of decline in the past five years. In the same year, just over $85 \%$ of ECl's nursing production was concentrated between Brazil and Spain, thus exercising a clear leadership position in the region. The publishing environment in both countries is substantially different. In Brazil, nursing journals are produced mainly in university contexts, while in Spain, publications by scientific societies and professional bodies are more frequent. Both models have in common the fact that they advocate open access, in contrast to the dominant one in the Anglo-Saxon context, highly commercialized by solid publishers.

Only two decades ago, Ibero-American nurses made few references to magazines produced outside their own country ${ }^{(4)}$. However, the use of ICE knowledge management tools such as SciELO ${ }^{(5)}$, as well as others of a disciplinary nature such as Careen ${ }^{(2)}$, has produced a change in its citation guidelines, becoming recognized in its potential to share knowledge contextualized socially and culturally. This does not mean that $\mathrm{ECI}$ nurses live behind what happens outside their region. In recent years, a new phenomenon has been taking over the scientific publication scene, the flight of knowledge to exogenous linguistic and disciplinary spaces. Many academic nurses and $\mathrm{ECl}$ researchers prefer to publish in biomedical journals in English because this gives them greater curricular value, in a context where the value of the bibliometric impact is imposed on the social. Clinical nurses, on the other hand, consume mainly scientific information in their own language and in journals in their closest subject area.

The gap between nurses who produce and nurses who consume is widening and puts editors in a dilemma as to the mission they must 
develop. What should your priority be? The dissemination of discoveries or the promotion of researchers? Do they put themselves at the service of nursing as a scientific discipline that needs to increase their visibility or that of the authors in their urgent need to publish? Many scientific journals have changed their business model in recent years, achieving greater profitability by charging authors for publication rather than readers for consumption. A practice that is incomprehensibly being adopted opportunistically by the nurse editors of $\mathrm{ECl}$, despite the fact that most journals are sponsored by public or non-profit bodies and supported by volunteer work.

Discovery and publication are two consequent exercises that are mutually supportive and are necessary to guarantee the progress of scientific knowledge ${ }^{(6)}$. In contrast, publishing without discovery only produces noise and does not contribute to the expected transformative effect of science. To publish for publishing means to exhaust the researchers' energies for an individual purpose, failing to contribute to the collective good. The disciplines that fall into this trap will no longer be sustainable because they cannot renew their intellectual capital.

Unfortunately, in many $\mathrm{ECl}$ countries science assessment systems are imposed that transform the discover = publish equation into another that gives meaning and value to the publication itself, using anachronistic criteria that artificially modify the uses among researchers. The best known and most criticized is the one that determines the importance of an article from the citations received by the magazine where it is published ${ }^{(7)}$. When the Impact Factor and its well-known language and territorial prejudices are adopted as an indicator of the quality of research activity, the ecological balance of science is altered. Hegemonic publishing environments are created at the same time that predatory practices are encouraged (between authors and publishers). But it also compromises the sustainability of journals of applied disciplines such as nursing, which have their own natural cycle of knowledge production and consumption, and are even marginalized if they do not adhere to this new false cycle.

On a recurring basis, groups of scientists take a stand against the need to adopt evaluation criteria that are more appropriate to the particularities of each discipline, to incorporate indicators that reflect the social impact of research. The growing aversion to the scientific community has been expressed by organizations such as the International Council for Science and through collective statements such as Dora or the Leiden Manifesto, or Degra in the field of nursing ${ }^{(8)}$. If scientific journals ignore the emerging demands that demand greater visibility for the scientific product and choose to cling to the business of the expectations of authors desperate to promote themselves, sooner or later they will be replaced by other forms of communication and will become a thing of the past. They will no longer be sustainable.

Fortunately, we found some reflexes of non-compliance that can be hopeful. A group of editors of nursing journals in the Ibero-American area has been working on the adoption of responsible editorial practices to give greater visibility to knowledge in nursing ${ }^{(9)}$. The principles they assume help us determine how to help ensure the sustainability of publications. Among them, greater professionalization of the editorial teams, recognition and encouragement for reviewers, transparency in the evaluation processes, cooperation between editors and, in general, the adoption of good practices in scientific communication ${ }^{(9)}$. It also alludes to the need to preserve the natural environment in which nursing knowledge is produced, avoiding the incorporation of practices that alter its ecological balance. With special reference to language care, promoting the use of vernacular languages as a means of sharing knowledge between researchers and citizens.

The responsibility for making $\mathrm{ECI}$ nursing journals sustainable rests largely with the editors themselves, depending on where we place the priorities. We can navigate in the wake of exogenous practices that only contribute to further obscure the knowledge of nursing, in favor of a supposedly universal science that exists only in dominant mentalities. Or we can resume the secular tradition of the evolution of nursing knowledge and legitimize the natural processes that give rise to this great intellectual heritage of our discipline. For, in doing so, we will contribute to widen the heterogeneous panorama of science, for which the diversities of currents converge that make it strong and socially useful. Nursing is undoubtedly one of them.

\section{REFERENCES}

1. Artaraz M. Teoría de las tres dimensiones de desarrollo sostenible. Ecosistemas 2002;11(2). https://doi.org/10.7818/ECOS.614

2. Amezcua M, Amezcua González A, Pozuelo Zurera S, Collado García JC, Herrera Justicia S. Recursos documentales CUIDEN y su utilidad para la evaluación del conocimiento en Cuidados de Salud. Index Enferm [Internet]. 2019[cited 2021 Feb 02];28(3):157-62. Available from: http:// scielo.isciii.es/scielo.php?script=sci_arttext\&pid=S1132-12962019000200014\&lng=es\&nrm=iso\&tlng=es

3. Amezcua M, Pozuelo Zurera S, Collado García JC, Amezcua González A, Herrera Justicia S. Ranking Cuiden Citación de Revistas de Enfermería más citadas en Iberoamérica: resultados del año 2019. Index Enferm [Internet]. 2020[cited 2021 Feb 02];29(1-2):96-9. Available from: https://ciberindex.com/index.php/ie/article/view/e52912

4. Gálvez Toro A, Hueso Montoro C, Amezcua M. Consumo de información de las revistas de Enfermería del área lingüística del Español y del Portugués (año 2002). Desarrollo Científ Enferm. 2004;12(3):69-76.

5. Nassi-Calò L. El Acceso Abierto como alternativa de sustentabilidad en la comunicación científica [Internet]. SciELO en Perspectiva, 2016[cited 2021 Feb 02]. Available from: https://blog.scielo.org/es/2016/01/14/el-acceso-abierto-como-alternativa-de-sustentabilidad-en-la-comunicacion-cientifica/

6. Amezcua M. From production to discovery: looking for the social impact of publications. Texto Contexto Enferm. 2015;24(2):299-300. https://doi.org/10.1590/0104-07072015EDITORIAL 
7. Aleixandre Benavent R, Valderrama Zurián JC, González de Dios J, Granda Orive Jl, Miguel-Dasit A. El factor de impacto: un polémico indicador de calidad científica. Rev Esp Econ Salud, 2004;3:242-52.

8. Reina Leal LM, Amezcua M, Red Internacional de Centros Colaboradores de la Fundación Index. Comentarios a DEGRA: Declaración de Granada sobre Conocimiento Enfermero. Index Enferm. 2013;22(4):246-7. https://doi.org/10.4321/S1132-12962013000300013 